\title{
Concepções de saúde no livro didático de ciências
}

Health conceptions in science textbooks

\author{
Elisângela Oliveira de Freitas ${ }^{1}$ \\ Isabel Martins \\ Programa de Pós-graduação Educação em Ciências e Saúde \\ Núcleo de Tecnologia Educacional para a Saúde \\ Universidade Federal do Rio de Janeiro
}

\section{Resumo}

Este trabalho discute quais concepções de saúde permeiam o texto de uma coleção de livros didáticos de ciências, utilizando a Análise de Conteúdo como definida por Bardin, para a análise dos textos como principal referencial metodológico. Observamos que, de forma geral, as concepções higienistas e as pautadas nos aspectos anatômicos/fisiológicos predominam nos livros da coleção analisada. O conceito mais amplo de saúde introduzido a partir da Conferência de Ottawa em 1986 foi pouco explorado pelos textos analisados. Vimos também que, no livro como um todo, não há muitas referências a uma visão mais ampliada da saúde, compreendida enquanto qualidade de vida e não apenas como ausência de doença. Esta maior ênfase nos condicionantes biológicos relacionados à saúde, que representa uma escolha criticada pelo PCN.

Palavras chave: Educação em saúde, Análise de conteúdo, Livro didático.

\section{Health conceptions in science textbooks}

This paper discusses which conceptions of health underlie a collection of science textbooks, using Content Analysis, as defined by Bardin, as the main methodological reference. Our results show that views of Health in connection with Hygiene and Biology were the most frequently present in the textbooks. Broader conceptions of Health, as those introduced by the Ottawa Conference in 1986, were fully explored. There were not many references to conceptions of Health as well being and not only as the absence of disease. The greater emphasis in Biological determinants represents a choice which is criticized by the Brazilian Curriculum Guidelines (PCN).

Key words: content analysis, health, science textbooks

\footnotetext{
${ }^{1}$ Apoio CAPES/DS
} 


\section{Introdução}

Como argumenta Soares (1996, p.55), o livro didático surge com a própria escola, estando presente ao longo da história, em todas as sociedades e em todos os tempos, não podendo ser compreendido isoladamente, sem que se leve em conta o contexto escolar e social. No contexto educacional brasileiro, a organização do trabalho no espaço escolar está muito vinculada ao uso do livro didático e, em muitos casos, este se constitui no principal referencial para o trabalho em sala de aula. Devido a sua penetração junto a um público leitor jovem, consideramos também que o livro constitui-se em material de referência, informação e consulta sobre diversos temas para muitos alunos. Estas considerações justificam nosso interesse de pesquisa sobre o livro didático.

Atualmente, as políticas públicas de educação representadas, principalmente pelos Parâmetros Curriculares Nacionais (PCN), constituem-se num dos mais importantes contextos de exigência no processo de produção de um livro didático. Os PCN sinalizam para a importância de buscar situações relevantes na vivência dos estudantes e tematizálas, e propõem um conjunto de temas que devem ser trabalhados transversalmente em todas as áreas de conhecimento. Ética, Saúde, Meio Ambiente, Pluralidade Cultural e Orientação Sexual foram os temas eleitos por serem problemáticas sociais atuais e urgentes, com abrangência nacional e até mesmo de caráter mundial. (BRASIL, 1997, p.45). Segundo Almeida (2006, p.3) os temas transversais favorecem, dentro do modelo educacional proposto pelos PCN, a formação integral da pessoa e a construção de uma sociedade mais igualitária, mais humana e solidária, o que não seria possível alcançar somente com a mera exposição dos conteúdos das disciplinas, sem articulação com o contexto sócio-cultural, com o mundo ao nosso redor.

Neste trabalho trataremos especificamente sobre como o tema saúde, é abordado numa coleção de livros didáticos de ciências.

\section{Referenciais para análise}

\section{Condicionantes de saúde}

Para entendermos como a saúde está sendo abordada no livro didático, achamos pertinente detalhar algumas interpretações dadas ao conceito de saúde, bem como ao processo saúde/doença. Cada sociedade tem um discurso sobre saúde/doença e sobre corpo, que, usualmente, se relaciona com sua visão de mundo e a realidade social. Podemos perceber que existe uma relação entre a forma de viver, adoecer e morrer e as condições sociais, o que nos permite relacionar as condições de vida, hábitos e adoecimento.

No ano de 1947, a Organização Mundial da Saúde (OMS) apresentou um conceito que contribuiu para o avanço em relação ao modelo biomédico (mecanicista/biológico) que considerava o corpo humano uma máquina e a saúde como o bom funcionamento desta máquina. De acordo com esta noção mais ampla: "saúde é o estado de mais completo bem estar físico, mental e social, e não apenas a ausência de enfermidade”. Esta nova definição pode ser considerada um avanço na medida que incorpora os aspectos mental e social como importantes para a saúde do individuo. Desta forma a saúde passa a ser de responsabilidade coletiva e não individual, como era encarada na perspectiva da compreensão mecanicista/biologicista, e muitos fatores passam a ser considerados como importantes para o alcance e a manutenção da saúde.

Apesar de representar um avanço, este conceito de saúde apresentado pela OMS recebeu criticas por ser pouco operativo, na medida em que bem estar é um conceito subjetivo e não mensurável. Além disso, é considerado pouco realista, pois remete a um estado 
estático, enquanto o processo de saúde pode ser considerado dinâmico (CARVALHO, 2006, p.8). No entanto, podemos destacar como positivo o fato deste conceito apontar para outros aspectos da saúde, além dos individuais. Em resumo, apesar de não se tratar de um conceito ideal de saúde, este conceito foi importante, pois a partir dele conceituações mais ampliadas surgiram.

Um marco histórico importante no desenvolvimento de um enfoque mais ampliado foi a I Conferência Internacional Sobre Cuidados Primários de Saúde, convocada em 1978 pela OMS em colaboração com o Fundo das Nações Unidas para a infância (Unicef), a qual se realizou em Alma-Ata, que passa a considerar as dimensões socioeconômicas, políticas, culturais e ambientes como fundamentais para a manutenção ou/e recuperação da saúde.

Estes avanços na conceituação de saúde passam a destacar aspectos psicológicos, sociais e ambientais, que não eram considerados até então (CARVALHO, 2006, p. 7-8), como condicionantes de saúde. Melo (1998, p.29-31) descreve alguns condicionantes de saúde como:

Condicionantes biológicos: conjunto de fatores relacionados diretamente ao próprio homem e que dizem respeito às suas características constitucionais, inerentes à anatomia e à fisiologia do organismo, bem como à herança genética;

Condicionantes psicossocias: conjunto de fatores que confirma a força da indivisível relação existente entre o corpo (estrutura biológica) e a mente (aspectos psíquicos). Por exemplo, a agressividade, a raiva, o comportamento depressivo ou a tendência ao isolamento são alguns fatores relacionados ao psiquismo humano que podem, eventualmente, determinar a ocorrência de algumas doenças, entre elas as psicossomáticas e as mentais;

Condicionantes culturais: grupo de fatores relacionados ao estilo e as condições de vida, como crenças, educação, hábitos, etc. Destacam-se em especial os hábitos relacionados à alimentação inadequada, ao consumo de bebidas alcoólicas, ao uso do fumo ou outras drogas e, ainda, ao sedentarismo;

Condicionantes sócio-econômicos: determinam o perfil, o modo de viver e até mesmo a forma de consumir das pessoas. Leva em conta as condições de habitação, lazer, alimentação, transporte e da própria saúde;

Condicionantes ambientais: as condições e as características ambientais estão estritamente associadas não só a ocorrência de diversos tipos de doenças, como também o agravamento ou ao aparecimento de muitas enfermidades infecto-contagiosas.

A determinação social da saúde/doença aparece como um novo conceito, sendo o processo saúde/doença determinado pelo modo como o homem se apropria da natureza em um determinado momento, apropriação que acontece por meio do processo de trabalho baseado em determinado desenvolvimento das forças produtivas e relações sociais de produção (DELIZOICOV, 1995, p.53).

Atualmente, adota-se um conceito de saúde, que engloba os recursos sociais e pessoais, assim como as capacidades físicas, onde as condições de vida e o estilo de vida são considerados (BARROS et al.; 2005, p.30). Este conceito multicausal da saúde, ao contrário da concepção unicausal, se preocupa com as diferentes ordens de complexidade dos fatores envolvidos com o processo saúde/doença, entendendo-o como sendo o resultado de uma teia de condicionantes sociais, econômicos, políticos, culturais, ambientais, comportamentais, psicológicos e biológicos (BARROS et al.; 2005, p.29). 


\section{'Educação em saúde' ou 'Educação para a Saúde'}

As concepções de saúde destacadas acima estão relacionadas a diferentes políticas e propostas de ações educativas. Uma inspeção mais cuidadosa revela que, embora na literatura as expressões "educação para a saúde" e "educação em saúde" sejam às vezes usadas de maneira indiscriminada, no debate político e acadêmico, realiza-se uma distinção entre elas, visando demarcar os campos políticos e ideológicos dos quais elas são consideradas representativas.

Ao realizar uma revisão dos usos dessas expressões e buscando construir uma síntese das concepções de educação, saúde e educação em saúde, Silva (2001) sistematiza a produção cientifica em duas vertentes: (a) a educação para a saúde, vinculada especialmente a informações sobre autocuidado e; (b) a educação em saúde, que envolve processos de ampliação da participação popular no acesso e na gestão de bens e serviços públicos. Segundo esta autora os programas de saúde escolar são pautados na primeira vertente, que se polariza com o segundo em função das diferentes concepções das "relações entre indivíduos e coletivos, entre saberes e poderes e entre Estado e sociedade" (SILVA, 2001, p. 19). "Educação em saúde" prevalece como expressão genérica, não necessariamente emblemática de qualquer das tendências assinaladas (VALADÃO, 2004, p.5).

Apesar dos PCN utilizarem a expressão "Educação para a Saúde”, neste estudo optamos por utilizar a expressão "Educação em Saúde” para designar, de uma forma geral, as experiências educativas organizadas com a finalidade de proporcionar oportunidades para a construção de conhecimentos teóricos e práticos em prol da saúde de indivíduos e da coletividade.

\section{A saúde nos livros didáticos}

No que diz respeito à abordagem da saúde nos livros didáticos de ciências podemos apontar a escassez de análises que envolvem este tema. Entre os estudos já realizados, destacamos os trabalhos de Alves (1987) e Mohr (1995) que criticam os conteúdos apresentados nos livros do ensino fundamental. Segundo estas autoras, os livros tendem a enfatizar mais os fatos do que as causas do processo saúde/doença, a valorizar excessivamente a memorização de nomenclatura técnica, e a apresentar meias verdades ou informações equivocadas, além de não se aproximarem do cotidiano do aluno. Além disso, os LDs também apresentam falhas quanto às atividades propostas (MOHR, 1995, p.94) uma vez que os exercícios propostos são, na sua maioria, mecânicos, se limitando a exploração visual e cópia de trechos do texto, não favorecendo a expressão própria, criativa e crítica do aluno. Para Alves (1987, p.44), os exercícios muitas vezes apenas tentam ocupar as crianças, não exigindo raciocínio. Já as sugestões para o trabalho em sala de aula sugeridas pela maioria dos livros didáticos analisados por estas autoras refletem uma visão de aprendizagem restrita, relacionada basicamente com a retenção de fatos, não levando os alunos à compreensão das causas do processo saúde/doença.

Num texto mais recente Mohr (2000, p.93), ao analisar livros didáticos do ensino fundamental, chama a atenção para a definição de saúde, feita de forma explícita e incorreta, que negligencia o componente social que consta na definição da OMS. A autora também chama atenção para as falhas com relação às ilustrações técnicas, destacando que o mais comum é a falta de indicação de escalas nos desenhos (MOHR, 1994, p.39). Já Delizoicov (1995, p.36), em sua análise, encontra uma concepção de saúde individualista e fragmentada, onde a manutenção da saúde é encarada do ponto de vista individual, focada em uma concepção unicausal do processo saúde/doença. A multicausalidade ou a determinação social desse processo não é levada em conta pelo texto. Mais adiante 
Delizoicov chama a atenção para o fato da doença ser abordada como um problema da falta de cuidado individual que permite o agente etiológico se instalar e atuar no organismo do indivíduo. Nesta perspectiva o indivíduo é culpabilizado por adoecer (DELIZOICOV, 1995, p.37). Este resultado não é muito diferente dos apresentados por Alves (1987, p.50), que destaca o fato do LD não buscar formas simples para levar o aluno a compreender e relacionar conteúdos que possibilitassem uma apropriação do conhecimento sobre seu corpo, mas, ao invés disso, optar por apresentar listas intermináveis de nomes para serem decorados. Alves também destaca que o preconceito e a discriminação são idéias que aparecem vinculadas nos textos abordando questões de saúde, relacionando a saúde às questões do "capricho pessoal" (ALVES, 1987, p.40). Carvalho (2002) em suas análises também encontrou resultados similares. Segundo essa autora a abordagem utilizada por uma coleção de LDs ao abordar saúde e doença, em especial a tuberculose, demonstrou que os autores tendem a utilizar uma dimensão quase que exclusivamente biológica as explicações dos processos fisio-patológicos no organismo humano, levando a um reducionismo.(in BERTOLLI FILHO, 2003, p.1).

Outros exemplos incluem o estudo realizado por Succi e colaboradores (SUCCI et al 2005, p. 77) que, ao analisar como se apresenta e discute o tema vacinação nos livros didáticos, constataram que 57,6\% dos livros apresentavam algum tipo de informação incorreta como, por exemplo, erros conceituais, erros na definição de vacina, erros no calendário vacinal, desatualização ou omissão de conteúdo e ilustração inadequada.

Finalmente destacamos as críticas de Bagnato (1990 apud Souza, 2001, p.13) que constatou também a predominância de conteúdos acerca de doenças sobre os conteúdos relacionados à saúde. Este autor também chama atenção para a separação entre temas relacionados à saúde e os demais conteúdos presentes no livro. Segundo ele, este formato de inserção da saúde no livro permite que se deixe sua discussão para o final do ano letivo, ou para quando sobra tempo.

\section{Metodologia}

\section{Objetivo e questões de estudo}

Neste estudo pretendemos ampliar e contribuir para o debate sobre como o tema saúde é abordado nos livros didáticos de duas formas. Primeiramente mapearemos as diferentes formas de inserção e abordagem de temas relacionados à saúde em um livro didático de grande circulação nacional. A seguir, discutiremos as diferentes concepções de saúde presentes no livro.

Nossas análises buscaram caracterizar os trechos selecionados para análise em termos de uma descrição orientada pelos itens abaixo relacionados:

a- Quais contextos temáticos relacionados à saúde são mais freqüentemente mobilizados?

b-Como se caracteriza a abordagem/tratamento destes temas?

c-O texto do livro se remete aos condicionantes de saúde de forma isolada ou em articulação?

d- Algum determinante (ou combinação de condicionantes) é mais relevante, ou mais freqüente?

\section{Corpus da pesquisa}

Para este estudo, após a inspeção de diversas coleções de livros didáticos de ciências para o segundo ciclo do ensino fundamental ( $5^{\mathrm{a}}$ a $8^{\mathrm{a}}$ séries, ou seja, do $6^{\circ}$ ao $9^{\circ}$ ano) decidimos 
pela análise de uma única coleção, numa tentativa de compatibilizarmos as demandas de uma análise textual e os limites de prazo para a conclusão deste estudo. Nossa escolha recaiu sobre a coleção "Ciências", de Carlos Barros e Wilson Roberto Paulino (Editora Ática), dada sua tradição, já que analisamos a 66ª edição desta coleção, lançada em 2005.

\section{Princípios de análise: análise de conteúdo}

Nesta investigação elegemos a análise de conteúdo, como posta por Bardin (1977) como principal aporte metodológico. A análise de conteúdo pode ser definida como um conjunto de técnicas de análise que faz uso de procedimentos sistemáticos e objetivos na descrição do conteúdo de mensagens, gerando indicadores (quantitativos ou não) que possibilitem a inferência de conhecimentos relativos às condições de produção/recepção (variáveis inferidas) dessas mensagens (BARDIN, 1977, p.38).

Nossa análise dos dados foi fundamentada na análise de conteúdo temática (BARDIN 1977. p. 77), entendida como um conjunto de instrumentos metodológicos que se aplicam a discursos diversificados. A análise temática consiste em buscar os "núcleos de sentidos" que estão inseridos em uma comunicação e cuja presença ou freqüência de aparição pode significar alguma coisa para o objetivo analítico escolhido" (BARDIN, 1977, p.105). Estes núcleos de sentidos que compõem a comunicação estão relacionados aos temas ou unidades de contexto.

De acordo com Bardin (1977, p. 106) o tema geralmente é utilizado como unidade de registro para quando se pretende estudar motivações de opiniões, de atitudes, de valores, crenças, de tendências etc., enquanto que a unidade de contexto serve de unidade de significação para codificar a unidade de registro, correspondendo ao segmento da mensagem, cujas dimensões são suficientes para que se possa compreender a significação exata da unidade de registro. Em nosso estudo, nossa unidade de registro está representada pelos parágrafos, que contêm palavras-chaves que estabelecem relação direta com questões relacionadas à saúde. Desta forma evitamos unidades de registro de pequena amplitude ou de amplitude muito grande, sem, contudo perder dados significantes para a análise

Selecionamos as unidades de registro, fazendo recortes de parágrafos em torno de cada unidade, as quais foram escolhidos por conterem as palavras-chaves destacadas a seguir: saúde, qualidade de vida, estilo de vida, vida saudável, práticas saudáveis, auto-cuidado, doença, prevenção, atendimento médico, transmissão, agente etiológico, agente transmissor e danos/prejuízos ao organismo. O recorte dos enunciados atenderam aos seguintes critérios, a fim de possibilitar uma analise consistente que possam responder as nossas questões de estudo.

- Tratam de temas relacionados à saúde nas diferentes visões/concepções presentes na literatura;

- Utilizam as palavras chaves destacadas acima.

- Não extrapolam os limites de um parágrafo.

No tratamento do material coletado utilizamos o programa Excel 2000 para obtermos as freqüências e as percentagens

\section{Procedimentos de análise e categorias analíticas}

A análise foi iniciada pela leitura exaustiva do texto de cada volume para a identificação dos textos relacionados às temáticas de saúde. Em seguida, elaboramos uma grade analítica que organiza estes textos, suas possíveis fontes (por meio da identificação de referências, 
explícitas ou não) e sua caracterização em função de alusões aos diferentes fatores que caracterizam diferentes concepções de saúde.

Com base na revisão da literatura estabelecemos uma caracterização das concepções de saúde que orientou nossas análises:

\section{Concepção higienista.}

Pautada na normatização, controle higiênico e eugenismo, segundo esta perspectiva a educação deveria trabalhar a consciência do indivíduo, assumindo o papel de transmissora de preceitos e normas médico-sanitárias, partindo da compreensão de que o indivíduo é responsável pela sua saúde, através da aquisição de uma consciência sanitária. Segundo Miranda (2000, p.85) a concepção higienista pode ser encontrada nos dias atuais, fortemente atrelada a algumas propostas da área da saúde. Podemos notar esta tendência, quando observamos as estratégias utilizadas no enfrentamento de epidemias - como dengue, cólera, febre amarela, malária e o retorno da tuberculose-, através de planos de combate sob forma de campanhas e de "dias nacionais", que tentam focalizar e tratar de maneira isolada tais problemas de saúde. Assim, ainda hoje, são utilizados, usualmente, os métodos de controle de hábitos de higiene, que responsabilizam o indivíduo pelo risco de adoecer. Nesta perspectiva, a escola teria por objetivo ensinar normas de higiene aos alunos e professores como forma prioritária de evitar adoecer, pressupondo que a prática de bons hábitos, somente, seria capaz de controlar as epidemias.

\section{Concepção com ênfase em aspectos biológicos/fisiológicos}

Relaciona a saúde apenas aos condicionantes biológicos e fisiológicos, numa perspectiva na qual corpo e mente estão dissociados. Segundo esta concepção o indivíduo é culpabilizado pela sua saúde. A doença é vista como um problema decorrente da falta de cuidado individual que possibilita a instalação da doença. As questões sócio-economicopolitica-ambientais não são levadas em conta.

\section{Concepção bio-psico-social}

Proposta pela OMS, em 1947, representa uma ampliação na conceituação do tema. Apresenta um conceito de saúde que pode ser apontado como um avanço já que ele inclui os aspectos mental e social como condicionantes importantes para a saúde do indivíduo.

\section{Promoção da saúde}

Concepção desenvolvida a partir de concepções ampliadas de saúde e que destaca "o processo de capacitação da comunidade para atuar na melhoria da sua qualidade de vida e saúde, incluindo uma maior participação no controle deste processo", sendo a saúde encarada como um recurso para a vida, tendo como condições e requisitos: paz, educação, moradia, alimentação, renda, ecossistema estável, recursos sustentáveis, justiça social e equidade (Carta de Ottawa, 1986, p.1)

Nossas análises buscaram encontrar relações entre tais concepções e o texto da coleção. A grade analítica utilizada é apresentada a seguir.

Tabela 1 - Grade analítica.

\begin{tabular}{|c|c|c|c|c|c|c|}
\hline Enunciado & Contexto & $\begin{array}{c}\text { Tipo de } \\
\text { texto }\end{array}$ & Localização & Fonte & Condicionantes & Observações \\
\hline $\begin{array}{l}\text { "Segundo o Instituto } \\
\text { Brasileiro de }\end{array}$ & $\begin{array}{l}\text { Pág } 72 \\
\text { Capítulo 7: }\end{array}$ & Informativo & \begin{tabular}{|l} 
Corpo \\
Principal
\end{tabular} & $\begin{array}{l}\text { Referência } \\
\text { direta, }\end{array}$ & $\begin{array}{l}\text { Sócio- } \\
\text { econômicos }\end{array}$ & $\begin{array}{l}\text { Relação direta } \\
\text { entre lixo e }\end{array}$ \\
\hline
\end{tabular}




\begin{tabular}{|c|c|c|c|}
\hline $\begin{array}{l}\text { Geografia e } \\
\text { Estatística (IBGE), } \\
\text { quase } 20 \% \text { do lixo } \\
\text { coletado no país é } \\
\text { jogado a céu aberto. } \\
\text { Os lixões a céu } \\
\text { aberto têm baixo } \\
\text { custo, mas } \\
\text { representam uma } \\
\text { ameaça à saúde } \\
\text { pública. Além de } \\
\text { exalar mau cheiro, } \\
\text { esses locais atraem } \\
\text { insetos e outros } \\
\text { animais que podem } \\
\text { causar sérios } \\
\text { problemas à nossa } \\
\underline{\text { saúde } \text { (grifos }} \\
\text { nossos). }\end{array}$ & $\begin{array}{l}\text { O ser } \\
\text { humano e o } \\
\text { meio } \\
\text { ambiente. } \\
\text { Subseção: } \\
\text { Seres } \\
\text { humanos e } \\
\text { impactos } \\
\text { ambientais: } \\
\text { alguns } \\
\text { exemplos }\end{array}$ & $\begin{array}{l}\text { porém } \\
\text { incompleta, } \\
\text { a estudo do } \\
\text { IBGE }\end{array}$ & $\begin{array}{l}\text { (ameaça à) } \\
\text { saúde. } \\
\text { Nos lixões } \\
\text { formam-se } \\
\text { resíduos que } \\
\text { contaminam o } \\
\text { solo e os } \\
\text { lençóis } \\
\text { subterrâneos } \\
\text { de água. } \\
\text { A população } \\
\text { mais carente é } \\
\text { a mais } \\
\text { prejudicada. }\end{array}$ \\
\hline
\end{tabular}

Na coluna enunciado transcrevemos os trechos do livro didático que dizem respeito ao tema "saúde". Na coluna intitulada contexto, localizamos o trecho destacado no livro, apontando a página, capítulo e seção de onde o trecho foi extraído. Já na coluna tipos de enunciados, buscamos destacar funções em termos de padrões discursivos tipicamente encontrados nos enunciados. A localização definiu se o trecho foi extraído do corpo principal ou se estava localizado em caixas de texto, exercícios ou textos complementares para leitura. A menção à fonte e à natureza das referências nos possibilitou analisar com quais textos o livro dialoga, se o texto incluía ou não referências a outros textos, e se as mesmas eram diretas ou indiretas. Na coluna condicionantes identificamos quais condicionantes relacionados à saúde (biológicos, psicossociais, culturais, ambientais ou sócio-econômicos) foram contemplados pelo livro didático. Finalmente, na coluna observação, registramos comentários que buscaram significar as observações feitas nas colunas anteriores.

Os tipos de enunciados foram classificados em: descritivo/explicativo, prescritivos, argumentativo, informativos e avaliativos, cujas descrições são apresentadas a seguir.

Tabela 2 - Tipos de enunciados

\begin{tabular}{|l|l|}
\hline \multicolumn{1}{|l|}{} & Características \\
\hline Tipos de texto & $\begin{array}{l}\text { Apresentam características e propriedades de conceitos. Estes enunciados } \\
\text { correspondem a sentenças que utilizam verbos ser, ter (possuir, conter etc.), } \\
\text { geralmente no presente simples. }\end{array}$ \\
\hline Explicativo & $\begin{array}{l}\text { Apresenta um fenômeno descrevendo seu mecanismo, destacando suas causas, } \\
\text { suas condições de funcionamento. }\end{array}$ \\
\hline Prescritivo & $\begin{array}{l}\text { Texto que de certa forma aponta procedimentos a serem seguido, geralmente } \\
\text { contém instruções. }\end{array}$ \\
\hline Argumentativo (reflexivo) & $\begin{array}{l}\text { De forma geral, este tipo de texto contém descrições de cenários ou situações que } \\
\text { contextualizam o problema e, a seguir, colocam perguntas diretas para o leitor. } \\
\text { Geralmente abordam de forma problematizadora uma situação do cotidiano do } \\
\text { aluno, ou que de certa forma despertam a curiosidade dos mesmos fazendo-os } \\
\text { pensar sobre a questão proposta. }\end{array}$ \\
\hline Informativo & Trazem dados relevantes sobre o conteúdo abordado, geralmente agrega dados \\
\hline
\end{tabular}




\begin{tabular}{|l|l|}
\hline \multicolumn{1}{|l|}{} & $\begin{array}{l}\text { estatísticos sobre uma determinada situação ou mencionam resultados obtidos por } \\
\text { organizações confiáveis. }\end{array}$ \\
\hline Avaliativo & $\begin{array}{l}\text { Tem a função de verificar a aprendizagem e envolvem análise, resolução de } \\
\text { problemas, cópia do texto, atividade extra-livro, resposta aberta, a serem } \\
\text { realizadas individualmente ou em grupo. }\end{array}$ \\
\hline
\end{tabular}

\section{Resultados}

Abaixo apresentamos uma tabela contendo a freqüência simples e percentual dos capítulos que abordam o tema transversal em questão.

Tabela 3 - Freqüência simples e percentual dos capítulos que abordam “saúde”

\begin{tabular}{|c|c|c|c|}
\hline Volume & $\begin{array}{c}\text { Número de capítulos que compõem o } \\
\text { volume }\end{array}$ & $\begin{array}{c}\text { Número de capítulos que abordam } \\
\text { "Saúde” }\end{array}$ & $\begin{array}{c}\text { Número de enunciados } \\
\text { sobre saúde }\end{array}$ \\
\hline $6^{\circ}$ ano & 24 & 7 & 28 \\
\hline $7^{\circ}$ ano & 24 & 7 & 168 \\
\hline $8^{\circ}$ ano & 17 & 16 & 172 \\
\hline $9^{\circ}$ ano & 21 & 2 & 371 \\
\hline Total & 86 & 32 & 371 \\
\hline
\end{tabular}

Ao analisarmos o volume do $6^{\circ}$ ano, destacamos 28 enunciados relacionados à saúde, distribuídos em sete dos 24 capítulos que compõem o volume e que tratam de "O ser humano e o meio ambiente”; “A água e a vida”; "A água e seus estados físicos”; "Tratamento de água e esgoto para todos”; “A composição do ar”; “A poluição ambiental” e; "Lixo: Problemas e soluções".

No volume do $7^{\circ}$ ano encontramos 168 enunciados relacionados a questões envolvendo "saúde". Estes enunciados estão distribuídos em sete dos 24 capítulos analisados, cujos títulos são: "Vírus: Seres sem organização celular"; 'Reino das moneras: as bactérias e as cianobactérias"; "Reino dos protistas: protozoários e algas unicelulares"; "Reino dos fungos"; "Os platelmintos e os nematelmintos"; “Os artrópodes” e; “Os répteis”.

Ao analisarmos o volume do $8^{\circ}$ ano encontramos 172 enunciados distribuídos em 15 dos 18 capítulos. São eles: "Níveis de organização do corpo humano"; "O sistema genital; "Como nascemos”; “Corpo, mente e 'coração’: os cuidados na adolescência”; "A vida continua”; "A importância dos alimentos”; “Alimentação saudável”; “A digestão”; "A respiração"; "A circulação"; "A excreção"; "Locomoção: ossos e músculos”; "Os sentidos"; "Sistema nervoso"; "Sistema endócrino".

Já no volume do $9^{\circ}$ ano encontramos somente três enunciados relacionados à saúde, em dois dos 21 capítulos que compõem este volume, que tratam dos seguintes conteúdos: "O átomo: estrutura e identificação" e "Substâncias e misturas".

Vemos assim que nesta coleção a maior freqüência de referências a temas relacionados à saúde ocorre no contexto da apresentação e discussão de tópicos relacionados ao corpo humano. Outras associações correspondem a relações entre saúde e ambiente e à descrição de doenças.

\section{Características dos enunciados}

\section{Tipos de enunciado}


Vimos que os enunciados se distinguem em função dos objetivos e da sua função dentro do texto da seção e do capítulo onde se inserem. De acordo com nossa classificação, os enunciados podem apresentar características descritivas/explicativa, informativas, argumentativas e avaliativas. Apresentamos a seguir uma classificação dos enunciados identificados. Nesta análise optamos por usar as categorias de forma excludente. Para isso, atribuímos a função de acordo com a característica mais marcante do enunciado.

Tabela 4 - Freqüência dos tipos de textos nos volumes da coleção

\begin{tabular}{|c|c|c|c|c|c|c|}
\hline Volume & Descritivo/explicativo & Prescritivo & Argumentativo & Informativo & Avaliativo & Total \\
\hline $6^{\circ}$ ano & 15 & 3 & 2 & 5 & 3 & 28 \\
\hline $7^{\circ}$ ano & 106 & 25 & 7 & 1 & 29 & 168 \\
\hline $8^{\circ}$ ano & 102 & 31 & 9 & 19 & 11 & 172 \\
\hline $9^{\circ}$ ano & 1 & 0 & 2 & 0 & 0 & 3 \\
\hline Total & 224 & 59 & 20 & 25 & 43 & 371 \\
\hline
\end{tabular}

Vemos que, com exceção do volume do $9^{\circ}$ ano, nos demais volumes da coleção predominaram enunciados descritivo/explicativos. Nestes enunciados encontramos freqüentemente os verbos ser, estar e ter, bem como variações como apresentar, manifestar, possuir ou conter, empregados no presente do indicativo. Encontramos também apostos enumerativos que listam propriedades, componentes relacionados a um dado conceito anteriormente apresentado, ou apostos explicativos, que esclarecem termos anteriores. São exemplos de enunciados descritivo/explicativo:

\section{"Embora a Aids seja comumente identificada como doença, na verdade trata-se de uma síndrome. A palavra síndrome caracteriza um conjunto de sinais e de sintomas que podem ser produzidos por mais de uma causa”. (Livro do $8^{\circ}$ ano. Capítulo 7, pág. 67) (grifos nossos). (aposto explicativo)}

Vimos também que a ênfase na descrição/explicação de conceitos ou termos não estava, geralmente, associada a demandas específicas de um determinado conteúdoPercebemos uma opção dos autores por uma apresentação de conteúdos que prioriza definições, descrição em termos de características observáveis ou propriedades, introdução à nomenclatura científica e exemplificação.

Em menor proporção, encontramos nos livros do $6^{0}, 7^{\circ}$ e $8^{0}$ anos enunciados de caráter prescritivo. Nestes textos encontramos o uso de verbos relacionados a dever e obrigação (dever, ter que etc.). Ao contrário dos enunciados com caráter descritivo/explicativo, que não se relacionavam a um conteúdo ou tema específico, os enunciados prescritivos estavam mais relacionados a situações envolvendo a adoção de medidas higiênicas, pessoais e coletivas, e de hábitos que ajudem tanto na prevenção de doenças/promoção da saúde quanto na não-degradação do ambiente. Entre os enunciados prescritivos, destacamos aqueles relacionados a situações contemporâneas e presentes no contexto nacional, envolvendo epidemias, tais como dengue, obesidade, doenças sexualmente transmissíveis.

"Depois de alguns minutos de ebulição, microrganismos e ovos de vermes que possam estar contidos na áqua morrem. É por isso que, não havendo filtro em casa, só devemos beber água que tenha sido fervida e guardada 
em recipiente limpo e fechado". (Livro do $6^{\circ}$ ano. Capítulo 14. p. 152). (grifos nossos).

Também encontramos enunciados do tipo avaliativos, que nos permitiram identificar como nas diferentes propostas de atividades contidas nestes, o autor aborda as questões pertinentes às questões de saúde. Dos 371 enunciados analisados nesta coleção, somente 43 possuem característica avaliativa, o que corresponde a aproximadamente $12 \%$ dos enunciados destacados. Deste total, observamos a presença marcante dos exercícios que exigiam a cópia do texto, já que os mesmos correspondem a mais de $65 \%$ das atividades. Atividades que exigiam análise e respostas abertas estão presentes em aproximadamente $16 \%$ e $14 \%$ respectivamente. As atividades extra-livro apareceram raramente, sendo encontradas em menos de $5 \%$ das atividades propostas. Atividades envolvendo resolução de problemas não aparecem nesta coleção. Vimos também que as atividades propostas eram quase que exclusivamente individuais, ou seja, não promovem debates e discussões entre os alunos. Mohr (1994) se deparou com resultados semelhantes ao analisar livros didáticos do primeiro ciclo do ensino fundamental.

Encontramos nesta coleção 25 enunciados informativos. Em alguns casos estes não só descrevem uma situação como agregam dados estatísticos sobre uma determinada situação e dados relevantes sobre o conteúdo abordado utilizando fontes confiáveis. A seguir exemplos de enunciados informativos:

“A OMS calcula que, a cada ano, quase 4 milhões de pessoas morrem em todo o mundo por doenças transmitidas por meio da áqua contaminada. As crianças são as vitimas mais freqüentes. (Livro $6^{\circ}$ ano. Capítulo 16. p. 167) (qrifos nossos).

Menos freqüentes foram os enunciados argumentativos, apenas 20 enunciados abordavam questões de saúde de forma contextualizada fazendo com que os indivíduos problematizem aspectos de ações cotidianas (ex. por que filtramos a água que vamos beber), introduzir explicações não intuitivas (ex. presença de microrganismos na água).

De forma geral, estes enunciados continham descrições de cenários ou situações que contextualizavam o problema e, a seguir, colocavam perguntas diretas para o leitor, como podemos observar nos exemplos destacados a seguir:

“Viroses são doencas causadas por vírus. Você já teve alguma virose? Citar dois exemplos de viroses que você e seus colegas de grupo já tiveram ou que acometeram pessoas da família”. (Livro $7^{\circ}$ ano. Capítulo6. p. 56) (grifos nossos).

\section{Localização dos enunciados}

Ao analisarmos a localização destes enunciados nesta coleção percebemos que os enunciados estão distribuídos de forma homogênea, estando presentes tanto no corpo principal, quanto em leituras complementares. Destacamos, no entanto, que as atividades propostas contemplam questões de saúde de forma modesta. Dos 371 enunciados analisados, 184 estão no corpo principal, 145 estão em leituras complementares e 43 são atividades propostas. Esta realidade muda quando analisamos os volumes separadamente, como podemos perceber na tabela a seguir:

Tabela 5- Localização dos enunciados

\begin{tabular}{|c|c|c|c|}
\hline Volume & Corpo Principal & Leitura Complementar & Exercícios \\
\hline $6^{\circ}$ ano & 21 & 5 & 3 \\
\hline
\end{tabular}




\begin{tabular}{|c|c|c|c|}
\hline $7^{\circ}$ ano & 90 & 59 & 29 \\
\hline $8^{\circ}$ ano & 73 & 88 & 11 \\
\hline $9^{\circ}$ ano & - & 3 & - \\
\hline Total & 184 & 145 & 43 \\
\hline
\end{tabular}

Podemos perceber que no volume do $6^{\circ}$ ano os mesmos são encontrados com maior freqüência no corpo principal do capítulo. Apenas cinco dos 28 enunciados estão em leituras complementares e três são propostas de atividades. No volume do $7^{\circ}$ ano, esta distribuição não é muito diferente, 90 enunciados estão no corpo principal, 59 em leituras complementares e 29 são enunciados que estão associados a atividades. Podemos perceber, no entanto que neste volume o número de exercícios abordando questões de saúde se faz mais presente. Uma nova realidade é encontrada no livro do $8^{\circ}$ ano, pois nele encontramos 73 enunciados no corpo principal, 88 enunciados estão em leituras complementares e apenas 11 são exercícios. No final do livro encontramos uma espécie de manual que aborda especificamente a questão da saúde e que é intitulado "Conservação da saúde: Breve história da medicina e da consciência ecológica” e um manual de primeiros socorros. A localização no final do livro pode ter o efeito de apresentar a saúde como um tema que não é prioritário em relação aos outros conteúdos. Relembramos aqui as considerações de Bagnato (1990) apud (Souza, 2001, p.14) que chama atenção para o fato de que, muitas vezes, estes temas acabam sendo abordados no final do ano letivo, ou quando sobra tempo. No $9^{\circ}$ ano encontramos os três únicos enunciados em Leituras Complementares. Este número reduzido de enunciados, associado, ao fato de que se encontram em material cuja leitura nem sempre é obrigatória sinaliza para dificuldades em operacionalizar a proposta da transversalidade do tema saúde no contexto de discussões relacionadas à Física e à Química.

Dos 371 enunciados destacados, percebemos que mais de $84 \%$ deles não contêm referências explícitas a outros textos, aproximadamente $13 \%$ apresentam referências diretas, geralmente na forma de citações a outros textos ou fontes, e menos de 3\% apresentam referência indireta. Dos 28 enunciados destacados no volume do $6^{\circ}$ ano, 24 não apresentam referência, dois apresentam referência direta e dois enunciados possuem referência indireta. As referências diretas e indiretas sinalizam que o volume mantém um dialogo com revistas (ex. Veja, Exame), jornais (ex. Folha de São Paulo) e documentos do IBGE. No volume do $7^{\circ}$ ano, onde foram analisados 168 enunciados, constatamos a presença de 139 enunciados que não se referem diretamente ou indiretamente a nenhuma fonte. Apenas 29 enunciados explicitam um dialogo do livro didático com outras fontes, entre elas, as páginas eletrônicas da Fundação Nacional de Saúde (Funasa) textos da Organização Pan-Americana de Saúde (OPS), do Ministério da Saúde, da Fundação Oswaldo Cruz (Fiocruz), e um livro paradidático. A situação não é muito diferente no volume do $8^{\circ}$ ano, onde a maioria dos enunciados não apresenta referência a outros textos. Observamos apenas algumas referências indiretas a textos da Organização Mundial de Saúde e outras poucas referências diretas a websites relacionados a temas científicos, às revistas Veja e Galileu, a jornais e a livros paradidáticos. No livro do $9^{\circ}$ ano apenas um enunciado apresentava referência direta a um livro paradidático.

Vemos assim que o livro possui um caráter híbrido no que diz respeito às referências principais que sustentam seu conteúdo que, de certa forma, ampliam horizontes de referência do saber científico-escolar para além dos tradicionais paradidáticos. As referências a websites, revistas e jornais de grande circulação como fontes de informação 
legitimada pelo livro podem tanto dizer respeito à necessidade de se remeter a contextos familiares de leitura quanto de estimular a leitura destes textos pelos estudantes. Da mesma forma aproxima-se o leitor de instituições de pesquisa e desenvolvimento na área da saúde.

\section{Condicionantes e concepções de saúde}

Buscamos também identificar nos enunciados referências aos condicionantes de saúde conforme destacamos na revisão da literatura. Na tabela 5 destacamos a freqüência de enunciados que articulavam referências a mais de um determinante, bem como a freqüência dos enunciados que articulam diferentes fatores. Observamos que nesta coleção didáticos os condicionantes relacionados à saúde aparecem freqüentemente de forma isolada, representando $73 \%$ dos enunciados. Apenas aproximadamente $22 \%$ apresentam condicionantes de forma articulada e cerca de $5 \%$, apesar de estarem relacionado à temática, não estão diretamente relacionados aos condicionantes tal como se apresentam na literatura consultada. Esta análise sugere que o livro trabalha com uma visão fragmentada da saúde, que não se alinha ao conceito contemporâneo na medida que este leva em conta a articulação dos diferentes condicionantes no processo saúde/doença.

Tabela 6- Condicionantes de saúde nos enunciados do livro didático

\begin{tabular}{|c|c|c|c|}
\hline Volume & $\begin{array}{c}\text { Enunciados contendo } \\
\text { referência a um único } \\
\text { condicionante de saúde }\end{array}$ & $\begin{array}{c}\text { Enunciados que articulam } \\
\text { diferentes condicionantes de } \\
\text { saúde }\end{array}$ & Não se aplica \\
\hline $6^{\circ}$ ano & 11 & 17 & 0 \\
\hline $7^{\circ}$ ano & 140 & 22 & 10 \\
\hline $8^{\circ}$ ano & 119 & 43 & 0 \\
\hline $9^{\circ}$ ano & 3 & 0 & 16 \\
\hline total & 273 & 82 & 0 \\
\hline
\end{tabular}

Podemos observar na Tabela 6 que apenas no $6^{\circ}$ ano existe um certo equilíbrio entre os enunciados que contem referência a diversos condicionantes de saúde de forma articulada e aqueles que os trazem isoladamente. Já ao analisarmos os volumes do $7^{0}$ e $8^{0}$ ano, encontramos em maior número os enunciados que apresentam condicionantes isolados e no $9^{\circ}$ ano só encontramos enunciados com condicionantes isolados. Na tabela 7 a seguir podemos identificar a freqüência e a porcentagem dos fatores isolados encontrados em cada volume que compõe a coleção analisada.

Tabela 7 - Freqüência dos condicionantes de saúde (isolados)

\begin{tabular}{|l|l|l|l|l|l|}
\hline Condicionantes & $6^{\circ}$ ano & $7^{\circ}$ ano & $8^{\circ}$ ano & $9^{\circ}$ ano & $\%$ \\
\hline Biológicos/fisiológicos & 1 & 130 & 109 & 3 & 89 \\
\hline Psicossociais & 0 & 0 & 6 & 0 & 2 \\
\hline Culturais & 0 & 0 & 1 & 0 & 0,4 \\
\hline Sócio-econômicos & 4 & 7 & 3 & 0 & 5 \\
\hline Ambientais & 6 & 3 & 0 & 0 & 3 \\
\hline Total & 11 & 146 & 129 & 3 & 100 \\
\hline
\end{tabular}


Dentre os enunciados que se remetem a um único condicionante de saúde presentes no livro do $6^{\circ}$ ano, encontramos em maior número os que se remetem a condicionantes ambientais, exemplificados a seguir:

\footnotetext{
“Tais atividades muitas vezes trazem prejuízos ao ambiente e aos seres humanos; podem, por exemplo, poluir o ar, se as indústrias lançarem quantidades significativas de certos gases na atmosfera.(Livro $6^{\circ}$ ano. Capítilo 7.p.71) Grifos nossos.
}

Esta concepção de saúde está intimamente relacionada à temática trabalhada neste volume, qual seja, meio ambiente. Esta relação foi também percebida por Mohr (1994, p.36) que, em seu estudo, chama atenção para a importância da abordagem de temas relacionados à saúde com o enfoque ecológico, onde o homem está inserido como parte do ecossistema. Porém, apesar dos conteúdos considerarem a influência do meio ambiente nas condições de saúde notamos que o autor deixa de relacioná-la aos outros condicionantes que também estão envolvidos no processo saúde-doença.

Dentre os enunciados analisados quatro se referem a condicionantes sócio-econômicos que estão relacionados ao modo de viver e até mesmo a forma de consumir das pessoas, levando em conta também às condições de moradia, lazer, alimentação, transporte e da própria saúde. No exemplo abaixo podemos observar a relação entre as condições de armazenamento do lixo e saúde:

"Segundo o Instituto Brasileiro de Geografia e Estatística (IBGE), quase $\underline{\mathbf{2 0} \% \text { do }}$ lixo coletado no país é jogado a céu aberto. Os lixões a céu aberto têm baixo custo, mas representam uma ameaça à saúde pública. Além de exalar mau cheiro, esses locais atraem insetos e outros animais que podem causar sérios problemas à nossa saúde ”(Livro do $6^{\circ}$ ano. capítulo 7, p. 72). (Grifos nossos)

Apenas um enunciado faz menção a condicionantes biológicos/fisiológicos, destacando aspectos relacionados às características anatômicas e fisiológicas, como podemos observar no exemplo abaixo:

\begin{abstract}
“O estrôncio 90 pode alojar-se em nossos ossos, próximo à medula óssea vermelha. A radioatividade emitida pode alterar a atividade da medula óssea e levar o indivíduo a uma forte anemia (deficiência na taxa de qlóbulos vermelhos no sanque) ou mesmo provocar leucemia-uma espécie de câncer, em que o indivíduo apresenta grande quantidade de glóbulos brancos no sangue”. (Livro do $6^{\circ}$ ano. Capítulo 21, p. 222). (Grifos nossos)
\end{abstract}

Não encontramos nenhum enunciado relacionado a condicionantes culturais ou psicossociais isoladamente. Isso indica uma dificuldade de apresentar uma visão mais ampliada do conceito de saúde, estabelecendo relações entre os meios biótico, físico, social e cultural para a manutenção e/ou recuperação da saúde.

As combinações mais freqüentes neste volume foram as de condicionantes sócioeconômicos com ambientais, e as de condicionantes biológicos/fisiológicos com ambientais. Encontramos cinco enunciados com cada uma destas combinações. Outra combinação freqüente foi a que relaciona os condicionantes culturais, sócio-econômicos e ambientais, neste caso destacamos quatro enunciados. Também encontramos dois enunciados articulando os condicionantes biológicos/fisiológicos, culturais e sócioeconômicos. Menos presente nos enunciados está à articulação entre condicionantes biológicos/fisiológicos e sócio-econômicos. Somente um enunciado fez essa articulação. Percebemos que a maioria dos enunciados contendo condicionantes articulados incluiu condicionantesambientais. Exemplos destes enunciados são apresentados na tabela 8. 
Tabela 8- Enunciados com referência a mais de um condicionante de saúde no livro do $6^{\circ}$ ano.

\begin{tabular}{|c|c|c|}
\hline $\begin{array}{l}\text { Enunciados com } \\
\text { referência a mais de um } \\
\text { condicionante de saúde }\end{array}$ & $\begin{array}{l}\text { Número de } \\
\text { ocorrências }\end{array}$ & Exemplo \\
\hline Biológicos e ambientais & 5 & $\begin{array}{l}\text { "Conforme o nível de monóxido de carbono na atmosfera, esse gás } \\
\text { pode provocar diminuição na nossa capacidade de visão, dores na } \\
\text { cabeça, tonturas e até mesmo a morte." (grifos nossos). }\end{array}$ \\
\hline $\begin{array}{l}\text { Biológicos, culturais e } \\
\text { sócio-econômicos }\end{array}$ & 2 & $\begin{array}{l}\text { “A expressão "louco como um chapeleiro" era muito popular no } \\
\text { século XVIII. Surgiu em conseqüência dos casos de distúrbios no } \\
\text { sistema nervoso que afetavam operários nas fábricas de chapéu de } \\
\text { feltro. Onde se manipulava mercúrio, um metal pesado". (grifos } \\
\underline{\text { nossos). }}\end{array}$ \\
\hline $\begin{array}{l}\text { Biológicos e sócio- } \\
\text { econômicos }\end{array}$ & 1 & $\begin{array}{l}\text { "O chumbo é outro exemplo de metal pesado. Seu acúmulo no } \\
\text { organismo humano provoca cólicas, vômitos, náuseas, perda de peso } \\
\text { e confusão mental, entre outros males. A poluição pelo chumbo é } \\
\text { provocada por indústrias diversas, como fundiçôes e industrias de } \\
\text { cristais”. (grifos nossos). }\end{array}$ \\
\hline $\begin{array}{l}\text { Culturais, sócio- } \\
\text { econômicos e ambientais }\end{array}$ & 4 & $\begin{array}{l}\text { “Ao cavar um poço é preciso escolher um local que fique a pelo } \\
\text { menos } 25 \text { metros de distância de fossas, depósitos de lixo e da } \\
\text { criação de animais. Microrganismos presentes nas fezes e no lixo } \\
\text { podem se infiltrar no solo juntamente com a água das chuvas, } \\
\text { contaminando o poço”.(grifos nossos). }\end{array}$ \\
\hline $\begin{array}{l}\text { Sócio-econômicos e } \\
\text { ambientais }\end{array}$ & 5 & $\begin{array}{l}\text { "segundo o Instituto Brasileiro de Geografia e Estatística (IBGE), } \\
\text { quase } 20 \% \text { do lixo coletado no país é jogado a céu aberto. Os lixões a } \\
\text { céu aberto têm baixo custo, mas representam uma ameaça à saúde } \\
\text { pública. Além de exalar mau cheiro, esses locais atraem insetos e } \\
\text { outros animais que podem causar sérios problemas à nossa saúde". } \\
\text { (grifos nossos). }\end{array}$ \\
\hline Total & 17 & \\
\hline
\end{tabular}

No volume do $7^{\circ}$ ano encontramos 140 enunciados que se referem a apenas um condicionante de saúde e 22 enunciados que se referem a vários deles. Percebemos que também há neste volume uma concepção de saúde onde predominam aspectos relacionados aos condicionantes biológicos/fisiológicos, tais como o exemplo a seguir:

"Entre as enfermidades provocadas por vírus nos seres humanos, podemos mencionar a Aids, a denque, a febre amarela, a gripe, $o$ resfriado, $a$ poliomielite, a catapora, a caxumba, o sarampo, a rubéola, a hidrofobia, a hepatite e o herpes”. (Livro do $7^{\circ}$ ano. Capítulo 6, pág 58).(grifos nossos).

Notamos que este volume trabalha predominantemente com uma concepção pautada nos aspectos anatômicos/fisiológicos,. Nesta perspectiva a saúde é entendida no seu caráter individual, estando cada individuo responsável pelo bom funcionamento do seu corpo. Nesta concepção outros componentes ganham papel menos importante para a manutenção e alcance da saúde. De fato, encontramos apenas sete enunciados relacionando saúde a condicionantes sócio-econômicos, neste caso as condições favoráveis de moradia, alimentação, acesso à água tratada, a vacinas estão relacionadas à saúde. Abaixo destacamos um exemplo:

“Repouso e boa alimentação estão entre os cuidados recomendados para que a pessoa resfriada se recupere mais rapidamente. (Livro do $7^{\circ}$ ano. Capitulo 6 . p.63) (grifos nossos)

Percebemos neste enunciado que a questão da alimentação é destacada sem, contudo fazerse referência às condições econômicas dos alunos. Os condicionantes ambientes estão presentes em três enunciados, um dos quais transcrito a seguir. 
"Transmitida ao ser humano por meio da picada do mosquito flebótomo (gênero Phlebotomus) - popularmente conhecido como mosquito-palha ou birigui, entre outras denominações-, recebe também o nome comum na cidade paulista de Bauru em tempos passados”. (Livro do $7^{\circ}$ ano. Capitulo 8. p.86) (grifos nossos)

Neste volume também não encontramos enunciados abordando os condicionantes psicossociais e culturais, reforçando a idéia de saúde fragmentada. Parece que realmente existe uma dificuldade em abordar a saúde em sua concepção mais ampliada. A exemplo de Mohr (1994, p. 51) vimos que o LD não aborda a saúde ou a doença de acordo com o enfoque das influências dos condicionantes do ambiente, físicos, biológicos e culturais, o que seria a perspectiva mais indicada para que o indivíduo possa formular seus próprios conceitos pois, dessa forma, ele estaria instrumentalizado para adotar ações e comportamentos mais coerentes com o estado de "saúde". Outro fato que nos chamou a atenção foi à preocupação com as informações técnicas sobre os ciclos biológicos neste volume da coleção.

Quanto aos enunciado que contém referência a mais de um condicionante de saúde, encontramos mais freqüentemente a combinação de condicionantes biológicos (doenças) e sócio-econômicos (condições de moradia precária), encontrada em nove enunciados entre os 22 enunciados que se remetiam a mais de um condicionante. A articulação de condicionantes biológicos/fisiológicos (invasão de microrganismos, doenças) e ambientais (veículos de transmissão estão relacionados a condicionantes ambientais) foi encontrada oito vezes neste volume. As articulações entre (a) os condicionantes biológicos/fisiológicos (doenças), culturais (vida saudável) e sócio-econômicos (condições favoráveis de moradia, alimentação, acesso à água tratada, a vacinas), (b) condicionantes sócio-econômicos e ambientais e (c) condicionantes biológicos/fisiológicos, ambientais e sócio-econômicos estão presentes em apenas um enunciado. Percebemos que, apesar disso, este volume tende a freqüentemente associar a saúde aos aspectos biológicos/fisiológicos que estão mais relacionados à concepção biologicista, como já descrevemos anteriormente. A tabela 9 apresenta a freqüência e exemplos dos enunciados analisados neste volume da coleção.

Tabela 9- Enunciados com referência a mais de um condicionante de saúde no livro do $7^{\circ}$ ano.

\begin{tabular}{|c|c|c|}
\hline $\begin{array}{l}\text { Enunciados com } \\
\text { referência a mais de } \\
\text { um condicionante de } \\
\text { saúde }\end{array}$ & $\begin{array}{l}\text { Número de } \\
\text { ocorrências }\end{array}$ & Exemplos \\
\hline Biológicos e ambientais & 8 & $\begin{array}{l}\text { "Também conhecida como paralisia infantil, a poliomielite é causada } \\
\text { por um vírus transmitido por gotículas de saliva e secreções } \\
\text { respiratórias eliminadas no ar ou por alimentos e } \\
\text { contaminados". (grifos nossos }\end{array}$ \\
\hline $\begin{array}{l}\text { Biológicos, culturais e } \\
\text { sócio-econômicos }\end{array}$ & 2 & $\begin{array}{l}\text { "Por isso, o melhor a fazer contra as viroses é evitar o contágio } \\
\text { dessas doenças; previnir-se tomando vacinas, quando existentes para } \\
\text { a doença que se quer prevenir e sempre com a devida orientação } \\
\text { médica; e manter fortalecido o sistema imunitário, levando uma vida } \\
\text { saudável. Isso inclui evitar certos hábitos (como o uso de fumo e } \\
\text { bebidas alcoólicas, por exemplo), dormir e alimentar-se bem, além } \\
\text { de adotar medidas higiênicas diversas, como lavar as mãos } \\
\text { principalmente antes das refeições, lavar frutas e verduras e beber } \\
\text { apenas água tratada ou fervida. (grifos nossos). }\end{array}$ \\
\hline $\begin{array}{l}\text { Biológicos e sócio- } \\
\text { econômicos }\end{array}$ & 9 & $\begin{array}{l}\text { "Os percevejos podem se alojar em frestas de paredes, chiqueiros e } \\
\text { paios. À noite, saem de seus esconderijos e vão sugar o sangue das } \\
\text { pessoas que estão dormindo. A doença pode ser contraída da seguinte } \\
\text { forma: durante a picada, o barbeiro infestado elimina fezes, que } \\
\text { contêm tripanossomos. Coçando o local da picada, a pessoa espalha }\end{array}$ \\
\hline
\end{tabular}




\begin{tabular}{|c|c|c|}
\hline & & $\begin{array}{l}\text { as fezes do barbeiro e acaba por introduzir os parasitas em seu } \\
\text { organismo por meio do pequeno orifício deixado pela picada. Uma } \\
\text { vez na corrente sanguínea, os tripanossomos atingem geralmente o } \\
\text { coração. Ali eles se fixam, podendo, em casos extremos, causar a } \\
\text { morte do doente.” (grifos nossos) }\end{array}$ \\
\hline $\begin{array}{l}\text { Biológicos, } \\
\text { ambientais e sócio- } \\
\text { econômicos }\end{array}$ & & $\begin{array}{l}\text { "Nosso organismo está sempre exposto à invasão de microrganismos } \\
\text { diversos. Eles podem penetrar no nosso corpo, por exemplo, por } \\
\text { meio do ar, da água, de ferimentos e de alimentos contaminados. } \\
\text { Alguns desses microrganismos podem ser patogênicos, isto é, } \\
\text { capazes de provocar doenças. Entretanto, nem sempre a doença se } \\
\text { manifesta; ao contrário, pessoas que, por exemplo, têm uma } \\
\text { alimentação saudável, vivem normalmente livres de doenças } \\
\text { provocadas por microrganismos". (grifos nossos). }\end{array}$ \\
\hline $\begin{array}{l}\text { Sócio-econômicos e } \\
\text { ambientais }\end{array}$ & 1 & $\begin{array}{l}\text { “Outra maneira de combater a malária consiste no uso de recursos } \\
\text { que evitem o acesso dos mosquitos às moradias, como a instalação } \\
\text { de telas protetoras em portas e janelas, por exemplo.”(grifos nossos) }\end{array}$ \\
\hline $\begin{array}{l}\text { Sócio-econômico e } \\
\text { Cultural }\end{array}$ & 1 & $\begin{array}{l}\text { "No povoado observou que umas grandes quantidades de insetos } \\
\text { hematófagas, popularmente denominadas barbeiros, viviam alojados } \\
\text { nas paredes de pau-a-pique das moradias. Decidiu examinar esses } \\
\text { insetos. Encontrou neles um novo parasita, que chamou de } \\
\text { Trypanossoma cruzi, em homenagem a Oswaldo Cruz. Verificou } \\
\text { também a presença desse parasita em animais domésticos. Mas foi } \\
\text { em } 23 \text { de abril de } 1909 \text { que Carlos Chagas descobriu pela primeira } \\
\text { vez o parasita no sangue de um ser humano: uma menina de } 3 \text { anos, } \\
\text { chamada Berenice". (grifos nossos) }\end{array}$ \\
\hline
\end{tabular}

No livro didático do $8^{\circ}$ ano encontramos 43 enunciados contendo referências a mais de um condicionante de saúde e 119 se referindo a um único condicionante. Dez enunciados, embora mencionando conteúdos ou contextos relacionados à saúde, não se remetiam a nenhum condicionante em particular, como destacamos no exemplo a seguir.

\begin{abstract}
"Antes de comecar um relacionamento sexual, no entanto, a mulher precisa consultar um qinecologista. Se o parceiro puder ir junto, melhor. O médico explicará os métodos apropriados ao casal e dará a orientação necessária ”.( Livro do $8^{\circ}$ ano, Capitulo 7. p.64) (grifos nossos).
\end{abstract}

Foram encontrados 109 enunciados se referindo apenas a condicionantes biológicos/fisiológicos isto é, trazendo aspectos relacionados à anatomia e fisiologia humana, o que se explica face ao predomínio de conteúdos de anatomia e fisiologia abordados nesta série. Identificamos também seis enunciados relacionados a condicionantes psicossociais. Este é o único volume no qual encontramos enunciados associando corpo e mente no processo de saúde, pouco abordados pela coleção em geral. Três enunciados se referiam a condicionantes sócio-econômicos, que estão relacionados a ações profiláticas relacionadas ao modo de viver e até mesmo a forma de consumir das pessoas. Apenas um enunciado se refere a condicionantes de natureza cultural culturais, o mesmo tenta de forma contextualizada abordar o hábito de fumar.

\footnotetext{
"Que o cigarro vicia, todo mundo sabe. Que não é fácil se livrar do vício, os fumantes que o digam. Será, então, que vale a pena começar a fumar?”. (grifos nossos)
}

Dentre os enunciados que combinam referências a mais de um condicionante de saúde, notamos que houve maior incidência da combinação entre condicionantes biológicos/fisiológicos (doenças) e culturais (estilo e as condições de vida, como crenças, educação, hábitos, etc.), representada por 21 enunciados. Encontramos dez enunciados articulando os condicionantes biológico/fisiológico e sócio-econômico, ou seja, relacionando doenças à situação econômica da população. Três enunciados relacionam os 
condicionantes biológico/fisiológicos (aspectos anatômicos e fisiológicos), culturais (estilo de vida) e sócio-econômicos (condições de habitação, transporte, lazer, alimentação e saúde). A combinação de condicionantes biológicos (doenças) e psicossociais (aspectos emocionais) apareceram três vezes em nossas análises. Somente no livro do oitavo ano observamos a presença de apenas dois enunciados que articulam todos os condicionantes de saúde, representando uma concepção atual de saúde. Finalmente encontramos um enunciado que relaciona os fatores biológicos/fisiológicos a condicionantes ambientais. Exemplos desses enunciados são listados na tabela, a seguir.

Tabela 10- Enunciados com referência a mais de um condicionante de saúde no livro do $8^{\circ}$ ano.

\begin{tabular}{|c|c|c|}
\hline $\begin{array}{l}\text { Enunciados com } \\
\text { referência a mais de } \\
\text { um condicionante } \\
\text { de saúde }\end{array}$ & $\begin{array}{l}\text { Número de } \\
\text { ocorrências }\end{array}$ & Exemplo \\
\hline $\begin{array}{l}\text { Biológicos e } \\
\text { ambientais }\end{array}$ & 1 & $\begin{array}{l}\text { “Ainda em meados do século XIX, Louis Pasteur (1822-95) compreendeu que } \\
\text { no ar existem microrganismos causadores de doenças. A partir daí, criou-se o } \\
\text { hábito de manter os hospitais sempre desinfetados, o que acabou promovendo } \\
\text { o aumento de cirurgias bem-sucedidas” (grifos nossos). }\end{array}$ \\
\hline $\begin{array}{l}\text { Biológicos e culturais } \\
\text { e sócio-econômicos }\end{array}$ & 3 & $\begin{array}{l}\text { “Uma gestante deve adotar certos cuidados durante a gestação, tais como: } \\
\text { - } \quad \text { Sua alimentação, como vimos, deve ser balanceada, como alias deve } \\
\text { ser a de qualquer pessoa. } \\
\text { - } \frac{\text { Não ingerir bebidas alcoólicas, não fumar ou consumir outro tipo de }}{\text { droga, pois essas substâncias podem causar danos a ela e ao }} \\
\frac{\text { feto.Medicamentos só devem ser tomados com a devida orientação }}{\text { médica. }} \\
\text { - } \begin{array}{l}\text { Qualquer alteração no organismo, como eliminação de sangue pela } \\
\text { vagina, contrações uterinas antes da data prevista para o parto, fortes }\end{array} \\
\text { - } \frac{\text { dores de cabeça ou abdominais, deve ser imediatamente comunicada }}{\text { A gestante deve ir ao médico periodicamente, seguir orientações e }} \\
\text { realizar todos os exames solicitados.”(grifos nossos). }\end{array}$ \\
\hline $\begin{array}{l}\text { Biológicos e sócio- } \\
\text { econômicos }\end{array}$ & 10 & $\begin{array}{l}\text { “O aborto clandestino é responsável pela morte anual de milhares de mulheres } \\
\text { em todo o mundo. } \mathrm{O} \text { problema atinge especialmente os paises menos } \\
\text { desenvolvidos. Segundo a Organização das Nações Unidas (ONU), nos } \\
\underline{\text { últimos anos realizaram-se cerca de } 50 \text { milhões de abortos clandestinos por }} \\
\underline{\text { ano, em todo o mundo }} . \text { No Brasil, estima-se atualmente que se realize cerca de } \\
\underline{1,4 \text { milhão de abortos clandestinos por ano, com a morte de aproximadamente }} \\
\underline{15 \text { mil mulheres por ano".(grifos nossos). }}\end{array}$ \\
\hline $\begin{array}{l}\text { Cultural e sócio- } \\
\text { econômico }\end{array}$ & 1 & $\begin{array}{l}\text { "Milhares de famílias da cidade de São Paulo estão em situação alimentar } \\
\text { abaixo da média recomendável. Se não passam fome diariamente, também não } \\
\text { se alimentam bem. Um dos problemas da fome é o desperdício. Apenas nas } \\
\text { feiras livres de São Paulo, mais de } 1000 \text { toneladas de alimentos vão para o } \\
\text { lixo todos os dias. Estima-se que cerca de } 80 \% \text { desse lixo poderia ser } \\
\text { reaproveitado. Muitas bancas de feiras doam o que sobra para a população } \\
\text { carente da região, mas ainda há quem jogue alimento no lixo". (grifos nossos) }\end{array}$ \\
\hline Biológicos e culturais & 21 & $\begin{array}{l}\text { “O HIV passa de uma pessoa para outra através de esperma, sangue e secreção } \\
\text { vaginal de pessoas contaminadas.Portando, pode-se adquirir o HIV: } \\
\qquad \quad \text { Por relação sexual com pessoa contaminada pelo vírus; } \\
\text { • Recebendo sangue contaminado pelo vírus; } \\
\text { Usando seringas e agulhas contaminadas pelo vírus;”. (grifos nossos). }\end{array}$ \\
\hline $\begin{array}{l}\text { Psicossociais e } \\
\text { culturais e sócio- } \\
\text { econômicos }\end{array}$ & 2 & $\begin{array}{l}\text { “Conservar esse espírito pode ser difícil, sobretudo nas grandes cidades. A } \\
\text { vida nos grandes centros urbanos torna-se cada vez mais agitada. Os } \\
\text { problemas aumentam constantemente: poluição atmosférica e sonora, } \\
\text { dificuldades nos transportes, assaltos, violência, miséria. A vida diária, para } \\
\text { muito dos habitantes, resume-se em trabalhar e dormir”.(grifos nossos) }\end{array}$ \\
\hline $\begin{array}{l}\text { Biológicos e } \\
\text { Psicossociais e }\end{array}$ & 2 & $\begin{array}{l}\text { "Violência, corrupção, desemprego, tráfego intenso, salários insuficientes, } \\
\text { doença. A lista de situações que provocam medo, tensão e angústia, entre }\end{array}$ \\
\hline
\end{tabular}




\begin{tabular}{|c|c|c|}
\hline $\begin{array}{l}\text { culturais e sócio- } \\
\text { econômicos }\end{array}$ & & $\begin{array}{l}\text { emoções e sentimentos que ameaçam o bem-estar das pessoas, não é pequena, } \\
\text { principalmente hoje em dia.” (grifos nossos). }\end{array}$ \\
\hline $\begin{array}{l}\text { Biológicos e } \\
\text { psicossociais }\end{array}$ & 3 & $\begin{array}{l}\text { “A saúde física, mental e emocional de qualquer pessoa está ligada, de alguma } \\
\text { forma, à saúde das células nervosas: os neurônios”. (grifos nossos). }\end{array}$ \\
\hline Total & 43 & \\
\hline
\end{tabular}

Percebemos que existe uma dificuldade em relacionar questões de "saúde" articulando condicionantes biológicos/fisiológicos e ambientais. Vale notar que o mesmo ocorreu, ao analisarmos o volume do $6^{\circ}$ ano, onde predominaram enunciados relacionados aos condicionantes ambientais. Ali também notamos que a referência contendo esta mesma combinação de condicionantestambém se deu de forma tímida.

No volume do $9^{\circ}$ ano encontramos somente enunciados relacionados exclusivamente acondicionantes biológicos/fisiológicos. Dos três enunciados destacados dois que se referem à questão da radioatividade ao abordar questões de "saúde" e um relacionado aos conceitos de substância e mistura, onde é destacado o conceito de água potável.

\begin{abstract}
"Os efeitos da radioatividade no ser humano dependem da quantidade acumulada no organismo e do tipo de radiação. Em pequenas doses, ela é inofensiva. Quando adequadamente empregados, os elementos químicos radioativos podem ser benéficos. O césio-137, por exemplo, é muito utilizado no tratamento de pessoas com tumores cancerosos. Mas doses excessivas podem provocar lesões diversas e até mesmo a morte”. (grifos nossos)
\end{abstract}

\title{
Discussão e conclusões
}

De forma geral, nossas análises apontam para uma visão reducionista e fragmentada de saúde, uma vez que, na maioria das vezes, está relacionada a um único condicionante. Além disso não foi possível perceber relações diretas entre uma dada concepção de saúde e o conteúdo estabelecido para uma dada série. Apesar de encontrarmos concepções que ampliam o conceito de saúde/doença, levando em conta os condicionantes sociais, culturais e econômicos, na coleção analisada uma forte relação entre saúde e condicionantes biológicos/fisiológicos, o que representa uma escolha criticada pelos PCN.

Este resultado também foi encontrado por Delizoicov em seu estudo (1995, p. 36). Examinando o total de enunciados presentes nos quatro volumes da coleção, constatamos a presença marcante dos condicionantes biológicos, encontrados em 243 dos 273 enunciados que mobilizavam apenas um condicionante, ou seja, em aproximadamente $90 \%$ dos enunciados destacados. São exemplos de enunciados relacionados a esta concepção:

“O chumbo é outro exemplo de metal pesado. Seu acúmulo no organismo
humano provoca cólicas, vômitos, náuseas, perda de peso e confusão mental,
entre outros males...” (Grifos nossos) (Livro: $6^{\circ}$ ano. Capitulo 21 , pág 221).

Além disso, muitas questões consideradas importantes para discussões da saúde, apesar de fazerem parte do cotidiano dos alunos, não aparecem nesta coleção. Questões relacionadas ao suicídio, anorexia, bulimia são exemplos de questões de "saúde" atuais que não são contemplados nesta coleção.

A concepção higienista, que marcou a formação de muitas gerações de brasileiros, tanto nas concepções relacionadas à saúde como à educação, e que pode ser notada ainda hoje na freqüente preocupação com a recomendação de cuidados e hábitos de limpeza (LOMÔNACO, 2004. p. 9), também foi observada no material analisado: 
"Para evitar o amarelão, é importante não andar descalço em solos que possam abrigar as larvas do parasita, além de ter cuidados higiênicos..." (Grifos nossos) (Livro: $7^{\circ}$ ano. Capitulo 16, pág 170).

O enfoque sanitário privilegiado nesta coleção é basicamente preventista. Resultados semelhantes foram destacados por Mohr (1994, p.50). Esta autora destaca que, apesar da importância do enfoque preventista, em alguns momentos é necessário que o indivíduo tenha informações que possibilitem a adoção de ações curativas. Assim como Mohr (1994, p.50), podemos citar como exemplo a abordagem dispensada ao tema das verminoses, onde não encontramos informações suficientes quanto ao tratamento das pessoas infectadas para que seja possível bloquear o ciclo de transmissão do parasita.

É importante destacarmos que os fatores psicossociais também não são abordados com muita freqüência nesta coleção, só encontramos questões relacionadas ao psiquismo humano que podem, eventualmente, determinar a ocorrência de algumas doenças, entre as quais encontramos as psicossomáticas e as mentais, no volume do $8^{\circ}$ ano. A relação entre os aspectos físicos e mentais também não são explorados.

Vimos também que o conceito mais amplo de saúde, introduzido a partir da Conferência de Ottawa em 1986, foi pouco explorado pelos textos analisados. Ele só está presente no volume do $8^{\circ}$ ano. Foram poucos os enunciados abrangendo o conjunto de fatores relacionados com a qualidade de vida, incluindo um padrão adequado de alimentação e nutrição, habitação e saneamento, boas condições de trabalho, oportunidades de educação ao longo de toda a vida, ambiente físico limpo, apoio social para as famílias e indivíduos e estilo de vida responsável.

Concepções mais ampliadas de saúde, presentes em enunciados tais como"Saúde significa bem-estar físico e mental. Portanto, a saúde resulta não só do equilíbrio de todas as funções que ocorrem no corpo, mas também da harmonia do ser com o meio ambiente" (Livro do $8^{\circ}$ ano, pág 228), foram encontradas, mas num anexo no final do LD. Sabemos que é muito comum o professor chegar ao fim do ano letivo sem ter chegado ao final do LD. Assim, o LD pode ter um conteúdo abordando "saúde", desenvolvida conforme preconiza as recomendações oficiais, porém esse conteúdo não ser abordado em classe. Outro exemplo é o anexo intitulado "Conservação da saúde: Breve história da medicina e da consciência ecológica”, também no final do livro do $8^{\circ}$ ano.

Com relação às temáticas relacionadas à saúde, destacamos que na sua relação com a nutrição, à abordagem dos temas relacionados à saúde nesta coleção didática limita-se a informar que funções os alimentos desempenham no organismo e quais doenças estão associadas a sua carência. São excluídos desta discussão os hábitos alimentares e as condições econômicas para seguir-se o cardápio ideal. A visão de saúde contemplada na abordagem deste conteúdo aproxima-se de um enfoque individualista. No que diz respeito aos conteúdos de saúde reprodutiva priorizam-se os aspectos anatômicos e fisiológicos, sem, contudo, contemplar aspectos relacionados à orientação sexual ou ir além da descrição das doenças sexualmente transmissíveis abordando questões sociais, a fim de que o aluno possa refletir e buscar adotar atitudes saudáveis para a vida em sociedade. Assim como nas análises de Delizoicov (1995) também percebemos nesta coleção a preocupação do autor em fornecer listas de nomes de agentes etiológicos e de doenças sem, contudo possibilitar uma discussão entre os indivíduos, o que reforça a ênfase na memorização o conteúdo abordado.

Em resumo, os enunciados relacionados à saúde que permeiam a coleção não articulam os condicionantes a ponto de fazer com que os indivíduos desenvolvam uma visão ampliada 
da saúde. Embora se reconheça que a co-existência das diferentes concepções de saúde que permeiam esta coleção pode ser reflexo dos questionamentos dos conceitos de saúde encontrados na própria área de conhecimento, percebemos uma fragmentação da visão de saúde contida nesta coleção, pois ao analisarmos separadamente os volumes notamos que de acordo com a temática da série uma visão é mais fortemente abordada..

Porém, se por um lado, as concepções de saúde encontradas nesta coleção podem ser consideradas limitadas, por outro, abre um campo de possibilidades para o professor criar e recriar, adotando outros textos para problematizar de modo contextualizado as questões de saúde no espaço social.

Apesar de, nossos resultados corroboram conclusões de estudos anteriores, acreditamos ter contribuído no sentido de ampliar as reflexões sobre como temas relacionados à saúde são abordados no LD. Em primeiro lugar consideramos que nossas análises fornecem uma visão mais global na medida em que tratam de uma coleção como um todo.Isto é importante, pois a adoção de uma mesma coleção para todas as series de um dado segmento, ao invés da adoção de livros de diferentes coleções para cada série, é mais comum por parte dos professores. Nesse sentido esta coleção poderia formatar as concepções de saúde a serem construídas pelos alunos. Em segundo lugar, esta escolha permite verificar em que medida diferentes temas relacionados à saúde estão sendo articulados. Outra contribuição é a identificação de se é feita, ou não, alguma relação entre temas transversais, por exemplo: saúde e orientação sexual ou saúde e meio ambiente.

Podemos também considerar que o caráter exploratório do estudo em questão dá margem à formulações de diferentes perguntas que podem inspirar outros estudos ou gerar hipóteses para futuras investigações.

\section{Referências}

ALMEIDA T. J. B. Abordagem dos Temas Transversais nas aulas de Ciências do Ensino Fundamental, no Distrito de Arembepe, município de Camaçari-BA. Candombá - Revista Virtual, v. 2, n. 1, p. 1-13, jan - jun 2006.

ALVES, N. C. A saúde na sala de aula:uma análise nos livros didáticos. Cadernos CEDES, 18: 38-53, 1987

BARDIN, L. Análise de conteúdo. Lisboa: Edições 70, 1977.

BARROS, C. M. S et al. Modelo de atividade Educação em Saúde, SESC/DN/DPD/GEP, 2005.

BERTOLLI FILHO, C.. A sociologia de Gilberto Freyre e a educação para a saúde. Ciência \& Educação, v. 9, n. 1, p. 105-121, 2003

BRASIL. Secretaria de Educação Fundamental. Parâmetros curriculares nacionais: terceiro e quarto ciclos do ensino fundamental: introdução aos parâmetros curriculares nacionais / Secretaria de Educação Fundamental. - Brasília : MEC/SEF, 1997.

CARTA DE OTTAWA- Carta de Ottawa sobre promoção de saúde, 1986. Disponível em:htpp://www.saudeemmovimento.com.Br/conteudoprint.aso?codnoticia=204 acesso em 14.02.2006 
CARVALHO, G.S \& CARVALHO, A.A.S. Educação para a saúde: Conceitos, práticas e necessidades de formação. Um estudo sobre as práticas de educação para a saúde, dos enfermeiros.Editora: Lusociencia, 2006

DELIZOICOV, N. C. O professor de ciências naturais e o livro didático (No ensino de Programas de saúde). Dissertação de Mestrado em Educação. Florianópolis. UFSC, 1995.

htpp://www.saudeemmovimento.com.Br/conteudoprint.aso?codnoticia=204 acesso em 14.02.2006.

LOMÔNACO, A. F. S. Concepções de saúde e cotidiano escolar - o viés do saber e da prática. In: 27a ANPEd, 2004, CAXAMBU. Sociedade, Democracia e Educação: Qual Universidade?. Petrópolis: Editora: Vozes, 2004. p. 7-423

MELO, E. C. P. Fundamentos de saúde-Ed Senac Nacional, 1998, 96p.

MIRANDA, M.I.F.de; IOSSI, M.A.; FERRIANI, M.das G.C.; CANO, M.A.T. Em busca da definição de pautas atuais para o delineamento de estudos sobre a saúde da criança e do adolescente em idade escolar. Rev.latino-am. enfermagem, Ribeirão Preto, v. 8, n. 6, p. 83-90, dezembro 2000.

MOHR, A. A saúde na escola: análise de livros didáticos de $1^{\mathrm{a}}$ a $4^{\mathrm{a}}$ séries. Dissertação (Mestrado). FGV Rio de Janeiro. 1994.

MOHR, A. A saúde na escola: análise de livros didáticos de $1^{\mathrm{a}}$ a $4^{\mathrm{a}}$ séries. Cadernos de Pesquisa, n.94, p.50-57,1995.

MOHR, A. Análise do conteúdo de 'saúde’ em livros didáticos. Ciência \& Educação, v. 6, n. 2, p. 89-106, 2000.

SILVA, F. K. M.. Análise das imagens geocientíficas em livros didáticos de ciências. Dissertação (Mestrado) Instituto de Geociências, UNICAMP, Campinas. São Paulo .2001

SOARES, M. B. Um olhar sobre o livro didático.Presença Pedagógica. V.2, nº 12. nov/dez.1996

SOUZA, M. L. M. Das técnicas aos fins: a Educação em saúde em duas escolas do ensino Fundamental. Dissertação (Mestrado) Núcleo de Tecnologia Educaional para a Saúde, UFRJ, 2001.

SUCCI, C. M. et al. A vacinação no conteúdo de livros escolares. Rev. Assoc. Med. Bras. vol.51 no.2 São Paulo Mar./Apr. 2005

VALADÃO, M. M. Saúde na Escola: Um campo em busca de espaço na agenda intersetorial. Tese (Doutorado), Departamento de Prática de Saúde. Universidade de São Paulo, 2004 